\title{
Pengaruh Inflasi Dan Nilai Tukar Terhadap Indeks Harga Saham LQ45
}

\author{
Tiar Lina Situngkir ${ }^{1}$, Reminta Lumban Batu ${ }^{2}$ \\ Fakultas Ekonomi dan Bisnis, Universitas Singaperbangsa Karawang, Indonesia \\ Email : tiarlina.situngkir@fe.unsika.ac.id
}

Direvisi : 03 /01/2020 Dipublikasikan : 27/01/ 2020

\begin{abstract}
Abstrak
Tujuan penelitian ini adalah untuk menganalisa pengaruh inflasi dan nilai tukar terhadap Indeks harga saham LQ45 di Bursa Efek Indonesia.Penelitian menggunakan Metode Error Correction Model yang menganalisa pengaruh variabel jangaka pendek dan jangka panjang. Hasil penelitian menunjukan pengujian secara parsial dan simultan individu variabel jangka pendek dan jangka panjang dapat dijelaskan sebagai berikut inflasi memiliki nilai koefisien estimasi sebesar -22.94 yang artinya meningkatnya nilai inflasi sebesar 22.94 akan berdampak penurunan indeks harga saham LQ45. Hasil penelitian menunjukan bahwa estimasi koefisien kurs -0.026 mengindikasikan bahwa meningkatnya nilai kurs senilai 0.026 akan berdampak penurunan indeks harga saham LQ45 senilai tersebut. Hal ini secara simultan dalam jangka pendek dan jangka panjang terbukti secara keseluruhan variabel bebas yang digunakan dalam penelitian ini berdamapk signifikan terhadap indeks harga saham LQ45.
\end{abstract}

Kata kunci : ECM, Inflasi, Kurs, LQ45

\begin{abstract}
The purpose of this study is to analyze the analysis of the value and exchange rate of the LQ45 stock price index on the Indonesia Stock Exchange. The study uses the Error Correction Model Method which analyzes short and long term variables. The results showed that the partial and simultaneous testing of individual short-term and long-term variables can be calculated as follows-estimated total estimate of -22.94 which means an added value of 22.94 will increase the LQ45 stock price index. The results showed that the estimated exchange rate coefficient of -0.026 would question the exchange rate of 0.026 would have an impact on the corresponding decline in the LQ45 stock price index. Simultaneously in the short run and long run it is proven that the independent variables used in this study have a significant effect on the LQ45 stock price index
\end{abstract}

Keywords : ECM, Inflation, Exchange Rate, LQ45 


\section{Pendahuluan}

Salah satu instrumen pasar modal yang menjadi alternatif untuk investasi yaitu saham. Apabila seorang investor berinvestasi dalam bentuk saham maka ada beberapa hal yang harus selalu memperhatikan faktor-faktor yang mempengaruhi harga saham yang akan dibelinya. Salah satu kelompok saham yang menjadi fokus perhatian investor adalah kelompok saham LQ45, hal ini dikarenakan saham LQ45 terdiri dari saham - saham blue chips, memiliki likuiditas yang tinggi, kapitalisasi pasar yang besar, frekuensi perdagangan yang tinggi dan memiliki prospek pertumbuhan serta kondisi keuangan yang cukup baik.

Setiap negara memiliki pasar saham masing-masing, pasar saham memfasilitasi pihak yang membutuhkan dana dan pihak yang memiliki dana (investor) sesuai dengan penelitian E.Tandelilin, 2012), perusahaan dapat memperoleh dana dengan menjual saham sedangkan investor dapat memperoleh keuntungan investasi berupa saham.

Penelitian dari Dewi \& Artini (2016) juga memaparkan bahwa suku bunga menjadi salah satu faktor yang mempengaruhi pergerakan indeks harga saham LQ45, demikian juga pendapat dari Suselo(2015) bahwa faktor makroekonomi secara fundamental akan mempengaruhi pergerakan indeks harga saham LQ45 yang sangat liquid karena banyak investor yang tertarik untuk bertransaksi di bursa ini. Hal ini menjadi selalu menarik untuk diteliti karena memang kehidupan kegiatan investasi sangat dipengaruhi oleh berbagai hal terutama faktor makroekonomi. Sehingga tujuan dari penelitian ini akan menganalisa pengaruh pergerakan faktor inflasi dan kurs terhadap indeks harga saham LQ 45.

\section{Metode Penelitian}

Model yang dipergunakan untuk dalam penelitian ini adalah Error Correction Model (ECM). Penelitian ini menggunakan metode korelasional karena bermaksud untuk melakukan pemaparan serta melakukan analisis mengenai pengaruh jangka pendek dan jangka panjang dari inflasi dan kurs terhadap return saham LQ 45. Penelitian ini menggunakan metode kuantitatif Error Correction Model (ECM).

Analisis data yang digunakan dalam penelitian ini meliputi: langkah pertama yang harus dilakukan adalah menguji stasioneritas data. Uji Akar-akar unit bisa dikatakan 
Doi (https://doi.org/10.33506/sl.v9i1.708)

sebagai uji stasioner karena pada prinsipnya, uji ini dilakukan apakah masing-masing variabel yang digunkan dalam penelitian bersifat stationer pada derajat no (level 0) atau derajat satu atau lebih tinggi. Apabila variabel ternyata stationer pada level, maka variabel tersebut dinakamakn Integrated Order Zero ( I0).

Jika variabel tersebut menjadi stationer setelah dilakukan difference 1 kali variabel itu dinamakan Integrated Order One ( I1). Pengujian unit root dilakukan dengan menggunakan Augmented Dickey Fuller ( ADF). Pengambilan keputusan dilakukan dengan kriteria : 1) Jika nilai statistik DF dan ADF > nilai tabel maka H0 ditolak atau data staioner 2) Jika nilai statistik DF dan ADF < nilai tabel maka H0 diterima atau data tidak stasioner Kriteria alternatif, yang dipakai dalam penelitian ini adalah : 1) Jika P Value dari ADF < 0.05 maka tolak H0. 2) Jika P Value dari ADF > 0.05 maka H0 tidak dapat ditolak

Langkah selanjutnya dalah uji derajat integrasi. Model awal yang digunakan dalam penelitian ini adalah sebagai berikut jangka panjang :

$$
\mathrm{Y}=\mathrm{a}+\mathrm{b}_{1} \mathrm{INF}_{1}+\mathrm{b}_{2} \mathrm{KURS}_{2}+\mathrm{e}
$$

Maka untuk jangka pendek dapat dituliskan persamaan ECM sesuai dengan hipotesis yaitu :

$$
\mathrm{DYt}=\mathrm{a}+\mathrm{b}_{1} \mathrm{INF} 1 \mathrm{t}+\mathrm{b}_{2} \mathrm{KURS}_{2 \mathrm{t}}+\mathrm{b}_{3} \mathrm{ECT}_{\mathrm{t}-1}
$$

\section{Hasil Dan Pembahasan}

Hasil Pengolahan dari statisitik deskriptof variabel penilitian dapat dilihat pada tabel 1 untuk variabel Indeks harga saham LQ 45 didapatkan nilai rata-rata adalah 877.6571 dengan tingkat standart deviasi adalah 93.50 menunjukan fluktuasi yang tejadi tidak terlalu besar periode 2003 sampai dengan 2018, ditampilkan dari angka maksimum adalah 1106 dan minimun adalah 93.5. 
Pengaruh Inflasi dan Nilai Tukar ...

Tiar Lina Situngkir

Tabel 1 Statistik Deskriptif

Doi (https://doi.org/10.33506/sl.v9i1.708)

\begin{tabular}{lccccc}
\hline \multicolumn{1}{c}{ Variabel } & Mean & Median & Maximum & Minimum & Std.Deviasi \\
\hline Indeks & 877.6571 & 875.5 & 1106 & 702 & 93.50 \\
LQ45 & & & & & \\
Inflasi & 5.054 & 4.35 & 8.79 & 2.79 & 1.903 \\
Kurs & 12721.79 & 13245.7 & 15178.87 & 9686.65 & 1332.38
\end{tabular}

Data : Sumber diolah

Tabel 1 Statistik deskriptif dari nilai Inflasi menunjukan bahwa pada periode 2013 sampai dengan 2018 menampilkan nilai rata -rata 5.054, standar deviasi sebesar 1.903 ini menunjukan volatilitas dari tingkat inflasi tidak besar malah cenderung menurun, dengan nilai maksimum 8.79 dan minimum 2.79 .

Variabel nilai tukar rupiah terhadap dolar pada peiode januari 2013 sampai dengan 2018 menampilkan mean 12721.79 nilai maksimum 15178.87 dan minimum 9686.65 serta standar deviasi 1332.38 memberikan gambar dalam periode ini nilai tukar mengalami fluktuasi yang tidak terlalu dalam. Pengolahan dengan metode ECM ada tiga tahapan yaitu pengujian akar - akar unit dan derajat integrasi, pengujian kointegrasi dan pengujian hipotesa model ECM baik untuk jangka pendek dan jangka panjang.

\section{Pengujian akar -akar unit dan derajat integrasi}

Indeks harga saham LQ45, Inflasi, dan kurs semuanya tidak stationer pada level, ditunjukkan oleh nilai probabilitas statistik DF > 0,05, seperti yang ditunjukan pada tabel berikut ini :

Tabel 2 Uji Akar - akar Unit ( level 0 )

\begin{tabular}{lccc}
\hline Variabel & DF Statistik & Probabilitas & Simpulan \\
\hline Indeks LQ45 & -1.374958 & 0.5896 & Tidak stationer \\
Inflasi & -1.833690 & 0.3615 & Tidak Stationer \\
Kurs & -0.094006 & 0.9454 & Tidak Stationer \\
\hline
\end{tabular}

Data : Sumber diolah 
Model ECM mensyaratkan semua variabel harus tidak stationer pada derajat level nol dan mencapai stationer pada derajat integrasi pertama. Hal ini dapat dilihat pada tabel 3. Hasil pengujian derajat integrasi menunjukkan bahwa semua variabel yang digunakan yaitu Indeks harga saham LQ45, Inflasi, dan Kurs mencapai stationer pada derajat 1 (first difference ) dengan nilai prob dari DF statistik < 0,05. Tahapan berikutnya adalah pengujian kointegrasi.

Tabel 3 Uji derajat Integrasi dejarat 1

\begin{tabular}{lccc}
\hline Variabel & DF Statistik & Probabilitas & Simpulan \\
\hline Indeks LQ45 & -7.524314 & 0.0000 & Stationer \\
Inflasi & -6.604812 & 0.0000 & Stationer \\
Kurs & -6.693884 & 0.0000 & Stationer
\end{tabular}

Sumber : Data diolah

Langkah berikutnya adalah uji kointegrasi, ditampilkan bahwa nilai probabilitas residual adalah 0.0128 ini memberikan simpulan bahwa $\mathrm{H} 0$ ditolak dan Ha diterima artinya ada hubungan jangka panjang antara masing-masing variabel, dalam hal ini hubungan indeks harga saham LQ45 dengan variabel bebas lainnya.

Tabel 4 Uji Kointegrasi

\begin{tabular}{llll}
\hline Variabel & DF statistika & Probabilitas & Simpulan \\
\hline RESIDUAL & 0.0128 & -2.507482 & berkointegrasi \\
\hline
\end{tabular}

Sumber : Data diolah

Hasil analisa uji unit root ( stationer ) atas Residual 01 adalah sebagai berikut : P.value adalah $=0.0146(<0.05)$ artinya sudah stationer . Kointergrasi yang terjadi antara variabel variabel yang digunakan dari koefision Resdual 01 adalah -0.166381 ( tanda minus memberikan makna memenuhi syarat sebgai adjustment factor ). Setiap bulan akan terjadi penyesuaian kurang lebih 6 bulan untuk menuju posisi normal. 
Pengujian Hipotesa

Doi (https://doi.org/10.33506/sl.v9i1.708)

\section{Model jangka Pendek}

Tabel 5 Model Jangka Pendek

\begin{tabular}{lcccr}
\hline Variable & Coefficient & Std. Error & t-Statistic & Prob. \\
\hline C & 1326.894 & $2.56 \mathrm{E}-12$ & $5.18 \mathrm{E}+14$ & 0.0000 \\
INFLASI & -22.94269 & $1.61 \mathrm{E}-13$ & $-1.43 \mathrm{E}+14$ & 0.0000 \\
KURS & -0.026198 & $2.30 \mathrm{E}-16$ & $-1.14 \mathrm{E}+14$ & 0.0000 \\
RESID01 & 1.000000 & $4.04 \mathrm{E}-15$ & $2.47 \mathrm{E}+14$ & 0.0000
\end{tabular}

Sumber : Data diolah

Model fit yang dihasilkan ( R2 adjusted ) sebesar 1 atau $100 \%$ memberi makna dalam jangka pendek semua variabel yang diuji mempengaruhi pergerakan indeks harga saham LQ45 secara penuh.

\section{Uji dampak simultan}

Pengujian secara simultan dengan uji F menghasilkan nilai $\mathrm{p}$ - value dari F sebesar $0 . .00<0.05$ membuktikan secara statistik paling tidak ada satu variabel independ yang berpengaruh signifikan terhadap variabel dependenya.

\section{Uji dampak parsial ( uji t )}

Hasil pengujian secara parsial individu variabel jangka pendek dapat dijelaskan sebagai berikut : 1) Inflasi memiliki nilai koefisien estimasi sebesar -22.94 yang artinya meningkatnya nilai inflasi sebesar 22.94 akan berdampak penurunan indeks harga saham LQ45. 2) Hasil estimasi koefisien kurs -0.026 mengindikasikan bahwa meningkatnya nilai kurs senilai 0.026 akan berdampak penurunan indeks harga saham LQ45 senilai tersebut. 


\section{Model ECM Jangka Panjang Koefisien determinasi}

Tabel 6. Koefisien determinasi

\begin{tabular}{lcccc}
\hline Variable & Coefficient & Std. Error & t-Statistic & Prob. \\
\hline \hline C & 1326.894 & 77.45723 & 17.13067 & 0.0000 \\
INFLASI & -22.94269 & 4.856762 & -4.723865 & 0.0000 \\
KURS & -0.026198 & 0.006940 & -3.775142 & 0.0003 \\
\hline \hline
\end{tabular}

$\begin{array}{lrr}\text { R-squared } & 0.554981 & \text { Mean dependent var } 877.6571 \\ \text { Adjusted R-squared } & 0.541697 & \text { S.D. dependent var } 93.50981 \\ \text { S.E. of regression } & 63.30437 & \text { Akaike info criterion } 11.17570 \\ \text { Sum squared resid } & 268498.7 & \text { Schwarz criterion } 11.27206 \\ \text { Log likelihood } & -388.1494 & \text { Hannan-Quinn criter. } 11.21397 \\ \text { F-statistic } & 41.77764 & \text { Durbin-Watson stat } 0.326669 \\ \text { Prob(F-statistic) } & 0.000000 & \end{array}$

Sumber : Data diolah

Model fit yang dihasilkan ( R2 adjusted ) sebesar 0.54 atau $54 \%$ memberi makna dalam jangka panjang semua variabel yang diuji mempengaruhi pergerakan indeks harga saham LQ45 sebesar $54 \%$ selebihnya $46 \%$ dipengaruhi oleh variabel lain yang tidak masuk dalam penelitian ini.

\section{Uji dampak simultan}

Pengujian secara simultan dengan uji F menghasilkan nilai $\mathrm{p}$ - value dari F sebesar $0 . .00<0.05$ membuktikan secara statistik paling tidak ada satu variabel independ yang berpengaruh signifikan terhadap variabel dependenya.

\section{Uji dampak parsial ( uji t )}

Hasil pengujian secara parsial individu variabel jangka pendek dapat dijelaskan sebagai berikut : 1) Inflasi memiliki nilai koefisien estimasi sebesar -22.94 yang artinya meningkatnya nilai inflasi sebesar 22.94 akan berdampak penurunan indeks harga saham LQ45. 2) Hasil estimasi koefisien kurs -0.026 mengindikasikan bahwa meningkatnya nilai kurs senilai 0.026 akan berdampak penurunan indeks harga saham LQ45 senilai tersebut. 


\section{Simpulan}

Pengaruh Inflasi dan Nilai Tukar ...

Tiar Lina Situngkir

Doi (https://doi.org/10.33506/sl.v9i1.708)

Berdasarkan hasil analisis yang telah dilakukan maka : 1) Inflasi dalam jangka pendek berpengaruh negatif signifikan terhadap indeks harga saham LQ45 demikian juga pada jangka panjang. 2) Kurs dalam jangka pendek berpengaruh negatif signifikan terhadap indeks harga saham LQ45 demikian juga pada jangka panjang. Secara simultan dalam jangka pendek dan jangka panjang terbukti secara keseluruhan variabel bebas yang digunakan dalam penelitian ini berdamapk signifikan terhadap indeks harga saham LQ45.

Implikasi Manajerial : Hasil penelitian menunjukan temuan bahwa kurs dan inflasi merupakan variabel bebas yang dalam jangka pendek dan jangka panjang berdampak negatif secara signifikan. Hal ini memberi sinyal bahwa kedua variabel itu mempengaruhi pasar valuta asing dan pasar modal di Indonesia. Otoritas keuangan moneter harus mampu membuat kebijakan makro yang bisa membuat situasi perekonomian stabil terhadap inflasi dan nilai tukar rupiah terhadap mata uang lain.

\section{Daftar Pustaka}

Andrew Patar. 2014.Faktor Internal dan Eksternal yang Mempengaruhi Pergerakan Harga Saham (Studi Pada Saham-Saham Indeks LQ45 Periode 2009-2013). Jurnal Administrasi Bisnis, 2014 - administrasibisnis.studentjournal.ub.

Ayu Dek Ira Roshita Dewi \& Luh Gede Sri Artini .2016. Pengaruh Suku Bunga SBI, Inflasi, dan fundamental Perusahaan Terhadap Harga Saham LQ45 di BEI. E-Jurnal Manajemen, 2016 - ojs.unud.ac.id.

D Suselo, A Djazuli, NK Indrawati.2015.Pengaruh Variabel Fundamental dan Makro Ekonomi terhadap Harga Saham (Studi pada Perusahaan yang Masuk dalam Indeks LQ45). Jurnal Aplikasi Manajemen, 2015 - jurnaljam.ub.ac.id.

Dedi Rosadi.2012.Ekonometrika \& Analisas Runtun Waktu Terapan dengan Eviews. Penerbit ANDI Yogyakarta.

E Tandelilin.2012. Manajemen Investasi. repository.ut.ac.id

Sriwardiningsih.2010. Dampak Pertumbuhan Ekonomi, Suku Bunga, Inflasi, dan Kebijakan Fiskal terhadap Investasi di Indonesia. Binus Business Review, 2010 journal.binus.ac.id

Maisaroh Fathul Ilmi. 2017. Pengaruh Kurs/ Nilai Tukar Rupiah, Inflasi dan Tingkat Suku Bunga SBI Terhadap Indeks Harga Saham Gabungan LQ-45 Periode Tahun 20092013. Jurnal Nominal / Volume VI / Tahun 2017. 
Nachrowi D Nachrowi \& Hardius Usman.2006. Pendekatan Populer dan Praktis Ekonometrika Untuk Analisis Ekonomi dan Keuangan. Lembaga Penerbit Fakultas Ekonomi Universitas Indonesia.

Kumar, N.P. \& Puja, P. 2012. The Impact of Macroeco- nomic Fundamentals On Stock Prices Revisited: An Evidence From Indian Data.MPRA PaperNo. 38980.

Suparno. 2010. Tingkat Inflasi dan Rasio Likuiditas terhadap Risiko Saham Syariah. Jurnal Telaah \& Riset Akuntansi, 3(1): 1-9.

Haroon, Muhammad A \& Hummera Jabeen, 2013. Impact of Macro- economic Variables on Share Price Behavior of Karachi Stock Exchange, Pakistan Journal of Commerce and Social Sciences vol 7 (3) 493-504.

Sri Mona Octafia. 2013. "Pengaruh Tingkat Suku Bunga SBI, Nilai Tukar dan Jumlah Uang Beredar Terhadap Indeks Harga Saham Sektor Property dan Real estate Dengan Pendekatan Error correction model." 1-10.

Suramaya Suci Kewal. 2012. "Pengaruh Inflasi, Suku Bunga, Kurs, dan Pertumbuhan PDB Terhadap Indeks Harga Saham Gabungan. Jurnal Economia vol 8 no 1, $53-64$. 